\title{
Data on the creation of new protected areas in the Nadym district of the Yamal-Nenets Autonomous Okrug
}

\author{
Valerii Glazunov $^{1 *}$, Svetlana Nikolaenko ${ }^{1}$, Stepan Senator $^{2}$ \\ ${ }^{1}$ Tyumen Scientific Centre SB RAS, Institute of the problems of Northern development, 625026 \\ Tyumen, Russia \\ ${ }^{2}$ Tsitsyn Main Botanical Garden RAS, 127276 Moscow, Russia
}

\begin{abstract}
The protected areas of the Nadym district are currently represented by only one nature reserve «Nadymskiy». This does not protect the biodiversity of the region. In 2020, we conducted a survey of the Nadym district in order to find new sites for the creation of protected areas. As a result, 7 new protected areas have been proposed: a natural park, a wildlife sanctuary and 5 natural monuments, including three lakes with a rare protected species of spore plants - Isoetes echinospora. The proposed protected areas cover the biodiversity of all natural zones of the Nadym district: tundra, forest-tundra and northern taiga. Some of the protected areas are of great historical and cultural importance for the aborigines.
\end{abstract}

The modern network of protected areas in the Yamal-Nenets Autonomous Okrug includes two federal reserves, a natural park and eleven regional wildlife sanctuaries. The total area of protected areas is $10.5 \%$, which is a fairly high figure. However, protected areas are unevenly distributed. In the Nadym district with an area of almost 100000 sq. km, there is currently only one protected natural area - the regional reserve «Nadymskiy» (created in 1986 for the preservation, restoration, reproduction of the most economically, scientifically and culturally valuable commercial species of animals; protection of rare animals listed in the Red Data Books; protection of natural landscapes, rare and valuable species of plants and plant communities). The area of the reserve is more than $5600 \mathrm{sq} . \mathrm{km}$. It is a reserve for flora and fauna of ecosystems on the border of the northern taiga and forest-tundra. The presence of only one protected area for the Nadym district does not provide biodiversity protection.

In 2020, we surveyed the territory of the Nadym district to identify areas that are promising for the creation of protected areas. Earlier, in the Nadym district, the number of finds of plant and animal species included in the national [1] and regional Red Data Books [2] was very small, so much attention was directed to finding new locations of rare species. As a result, data were prepared to give the status of protected 7 territories, including 1 wildlife sanctuary, 1 natural park, 5 natural monuments (the list and areas in Table 1).

\footnotetext{
*Corresponding author: $\underline{\text { v_gl@inbox.ru }}$
} 
Table 1. Prospective protected areas in the Nadym district

\begin{tabular}{|c|l|l|c|}
\hline № & \multicolumn{1}{|c|}{ Name } & \multicolumn{1}{c|}{ Category } & Square, sq. km \\
\hline 1 & $\begin{array}{l}\text { Larch forest near the } \\
\text { Mongayurbey river }\end{array}$ & Natural monument & 11,81 \\
\hline 2 & $\begin{array}{l}\text { Holy Cape } \\
\text { Khebidya-Sale }\end{array}$ & Natural monument & 2,44 \\
\hline 3 & Lake Svetloe & Natural monument & 1,95 \\
\hline 4 & Lake Norinskoe & Natural monument & 0,673 \\
\hline 5 & Blue Lake Verykort & Natural monument & 3,04 \\
\hline 6 & Nizhnenadymskiy & Wildlife sanctuary & $\begin{array}{c}\text { Version 1 - 3007 } \\
\text { Version 2 - 6412 }\end{array}$ \\
\hline 7 & Numto & Natural park & $\begin{array}{c}\text { Version 1 - 7766 } \\
\text { Version 2 - 18690 }\end{array}$ \\
\hline
\end{tabular}

Natural monument «Larch forest near the Mongayurbey river». One of the northernmost communities of taiga vegetation in Western Siberia. The forest is located on the northern border of the Siberian larch range and is unstable to various forms of impact. The natural monument is located southwest of the confluence of the Mongayurbey and Kharvuta rivers, on the border with the Tazovsky district. The geographic coordinates of the center of the site are $67.788544^{\circ} \mathrm{N}, 76.675954^{\circ} \mathrm{E}$. The natural monument is located within the floodplain and above-floodplain terraces of the Mongayurbey River. The territory of the natural monument is a slightly sloping plain with swamps and lakes - the valley of the Mongayurbey River and adjoining interfluvial spaces with small rivers and streams. A large number of lakes are river oxbows.

The larch forest is the «core» of a promising natural monument, occupies the edge of the watershed and the terrace above the floodplain. On the edge of the watershed there is a larch forest of medium density, the height of the trees is $10-12 \mathrm{~m}$. The ground cover is grass - shrub - green moss. On the terrace there is a larch forest with a sparse tree layer and shrub-lichen cover.

More than 100 species of vascular plants grow on the territory of the natural monument. One plant species included in the main list of the Red Data Book of the Yamal-Nenets Autonomous Okrug [2], was discovered - Polemonium boreale (category 3, rare species). The species grows on sandy soil along the river bank.

On the banks of the Mongayurbey River Aster sibiricus is found. The species included in the addition to the Red Book of the Yamal-Nenets Autonomous Okrug (2010) - a list of species that need special attention to their state in the natural environment.

Larch (Larix sibirica) is a relict (boreal transgression of the Holocene) species on the northern border of the range. The trees are 400 years old or more.

Natural monument «Holy Cape Hebidya-sale». The cape is located $14 \mathrm{~km}$ northwest of the estuary of the Nadym River, on the right side of the confluence of the Khebidyayakha River to the Gulf of $\mathrm{Ob}\left(66.307778^{\circ} \mathrm{N}, 71.660833^{\circ} \mathrm{E}\right)$.

The slope of the coast of the Gulf of $\mathrm{Ob}$ here is up to $30 \mathrm{~m}$ above the water's edge, the slope is $35-50^{\circ}$. Then the slope decreases and gradually becomes gentle. In the eastern, low part, there is a site with thick modern marsh sediments. Peat is located under a community of Betula nana, shrubs and lichens. The height of peat deposits is more than $1 \mathrm{~m}$. Various geological processes take place here: erosion of ravines, landslides and talus, solifluction. There are large and small stones on the coast, some of them have blurred edges - evidence of the transfer by the glacier. Paleontological material was found here - mammoth bones. 
The vegetation of the territory is a combination of larch forests (near the northern border of the area and shrub-moss tundra. High areas are covered with larch forest with a rare tree layer. Shrub-green moss and shrub-lichen associations. Low trees (7-8 m). Gentle slopes are occupied by tundra low shrub - lichen and low shrub - grassy - moss communities. Small in area brakes of Alnus fruticosa can be found. At the edge of the terrace there are short ravines and cracks in peat. The slope of the alluvial-marine terrace is partially covered with vegetation (dominated by Descurainia sophioides, Rorippa dogadovae, Tripleurospermum hookeri, Funaria hygrometrica) In the brakes of Alnus fruticosa, there is Goodyera repens, a species included in the additional list of the regional Red Data Book [2].

The Cape is an important site in the aboriginal religion.

Natural monument «Lake Svetloe». The lake belongs to the category of «blue lakes» (oligotrophic, with clean, transparent water). The lake contains a population of a rare aquatic plant Isoetes echinospora - a species included in the Red Data Book of Russia (category 2 - a species that is declining in numbers). The lake is located $2 \mathrm{~km}$ south of Novy Urengoy $\left(66.057881^{\circ} \mathrm{N}, 76.613517^{\circ} \mathrm{E}\right)$.

Larch forests with rare trees prevail along the shores of the lake; there are areas of mixed forests with Larix sibirica and Betula pubescens. Betula nana forms the shrub layer. Low shrubs of Empetrum nigrum, Vaccinium myrtillus, Vaccinium uliginosum. Coastal aquatic vegetation dominated by Carex rostrata, Carex aquatilis. Aquatic vegetation from Sparganium angustifolium. Isoetes echinospora grows on a wide sandbank and forms a community at a depth of $0.4 \mathrm{~m}$ and deeper [3]. There is a strong recreational impact.

Natural monument «Lake Norinskoe». The lake is located $5.5 \mathrm{~km}$ north of the village Nori $\left(66.206944^{\circ} \mathrm{N}, 72.397778^{\circ} \mathrm{E}\right)$, in a remote inaccessible area. The lake belongs to the category of «blue lakes». Anthropogenic impact - residents visiting the settlement of Nori for sampling clean drinking water. Water is collected, as a rule, in winter, using snowmobiles.

Around the lake there are shrub-sphagnum boggy tundras, birch-larch forests with low shrubs (Vaccinium uliginosum, Vaccinium myrtillus, Vaccinium vitis-idaea, Ledum palustre). There is an intermittent strip of Betula pubescens along the lake shore.

At the bottom of the lake there are numerous populations of Isoetes echinospora (Red Data Book of Russia, category 2 - a species decreasing in numbers) and Subularia aquatica (Red Data Book of the Yamal-Nenets Autonomous Okrug, category 4 - a species with an undefined status).

Natural monument «Blue Lake Verykort». The lake with an area of $1.1 \mathrm{sq} . \mathrm{km}$ is located in the southern part of the Nadym district, $27 \mathrm{~km}$ northeast of the village Priozerny $\left(64.386889^{\circ} \mathrm{N}, 71.580208^{\circ} \mathrm{E}\right)$. The lake belongs to the category of «blue lakes». Previous hydrochemical analysis revealed an abnormally low iron content - less than the detection limit. The lake is elongated in a latitudinal direction, has an irregular shape and a large promontory near the northern shore. The name «Verykort» had a former settlement near the lake. Along the shore of the lake there is a coastal rampart with a pine-birch forest and bog species (Ledum palustre, Chamaedaphne calyculata, Andromeda polifolia, Rubus chamaemorus). There are Vaccinium vitis-idaea, Vaccinium myrtillus. Lichens are present in the upper part of the shaft. Juncus filiformis, Sparganium angustifolium, Isoetes echinospora grow in the lake in shallow water. Pine lichen and lingonberry-lichen forests are located around the lake. The eastern shore of the lake is swampy.

Wildlife sanctuary «Nizhnenadymskiy». The site is located in the lower course of the Nadym River, $30 \mathrm{~km}$ upstream from the estuary. It is a floodplain complex of the foresttundra zone with a wide variety of forest vegetation. Two variants of boundaries have been proposed, taking into account the interests of the indigenous population - maximum and minimum, occupying only the left-bank section of the floodplain of the Nadym River. 
A well-pronounced latitudinal change of landscapes is observed. The southern part is dominated by forest communities of mixed composition (Betula pubescens, Pinus sibirica, Picea obovata, Larix sibirica). Towards the north, Betula pubescens and Larix sibirica remain in the tree layer. At the estuary of the Nadym River, woody vegetation almost completely disappears; communities of willow and floodplain meadows are formed along the banks.

Along riverbeds and channels, there are strips of alluvial deposits with unclosed groups of herbaceous plants. At a height of 1-1.5 m from the water's edge, there are shrubs (willow) or herb-grasses, sedge and sedge-reed meadows. In the highest parts of the floodplain, there are birch grass-moss forests.

Goodyera repens is found in the floodplain of the Nadym River (additional list of the Red Book of the Yamal-Nenets Autonomous Okrug). 8 specimens were found in a mixed dwarf-reed forest $\left(65.684148^{\circ} \mathrm{N}, 72.543479^{\circ} \mathrm{E}\right)$.

Natural Park «Numto». Located in the southern part of the Nadym region, on the border with the Khanty-Mansi Autonomous Okrug - Yugra, near Lake Numto and the source of the Nadym River. The territory is complemented by the adjacent operating natural park «Numto» with an area of 5560 sq. $\mathrm{km}$ in the Beloyarsky district. Two variants of the boundaries have been proposed, taking into account the promising areas of oil production.

The territory, according to the criteria of the Ramsar Convention on the Protection of Wetlands, is a representative area of the northern taiga marsh landscapes with typical marsh flora and fauna. Of interest is the presence of flat-hilly peat bogs, similar to typical tundra. There are large-hilly bogs, characteristic of the northern taiga, and ridge-hollow bogs.

Forests are spread along rivers. Dark coniferous (Picea obovata, Pinus sibirica) forests with the participation of Betula pubescens and Pinus sylvestris grow directly near the channels. Also, rivers and large lakes have swampy birch forests. The terraces above the floodplain are occupied by pine low shrub and lichen forests.

There is Lycopodiella inundata (Red Data Book of the Yamal-Nenets Autonomous Okrug, category $4-$ a species with an undefined status). The species is noted between the Numto Lake and Murayakha River $\left(63.512319^{\circ} \mathrm{N}, 71.566768^{\circ} \mathrm{E}\right)$. A large population on a peaty and sandy substrate, along the edge of a low birch forest.

Lake Numto with the adjacent territory is the most important cult object in the traditional worldview of the aboriginal population - the Khanty and the Nenets.

The implementation of proposals for the organization of protected natural areas in the Nadym district, in addition to the existing wildlife sanctuary «Nadymsky», will make it possible to form a system of protected areas that is representative of the biodiversity of the territory and effectively performs the functions of protecting the environment and resources.

\section{References}

1. Red Data Book of the Russian Federation (plants and mushrooms) (Limited Liability Company Partnership of Scientific Publications KMK, Moscow, 2008)

2. Red Data Book of the Yamal-Nenets autonomous okrug: animals, plants, fungi (Yekaterinburg, Basko, 2010)

3. A. V. Verkhozina, R. Yu. Biryukov, E. S. Bogdanova et al., Botanica Pacifica, 10 (1) (2021) 